\title{
Optimization and Encapsulation of Phenolic Compounds Extracted from Maize Waste by Freeze-Drying, Spray-Drying, and Microwave-Drying Using Maltodextrin
}

\author{
Hojjat Pashazadeh ${ }^{1, *(\mathbb{D})}$, Oscar Zannou ${ }^{1}(\mathbb{D})$, Mohamed Ghellam ${ }^{1}\left(\mathbb{D}\right.$, Ilkay Koca ${ }^{1}$ (D) Charis M. Galanakis ${ }^{2,3,4, *(\mathbb{D})}$ \\ and Turki M. S. Aldawoud ${ }^{4}$ \\ 1 Food Engineering Department, Faculty of Engineering, Ondokuz Mayis University, 55139 Samsun, Turkey; \\ zannouoscar@gmail.com (O.Z.); mohamed.gh2010@gmail.com (M.G.); itosun@omu.edu.tr (I.K.) \\ 2 Research \& Innovation Department, Galanakis Laboratories, 73100 Chania, Greece \\ 3 Food Waste Recovery Group, ISEKI Food Association, 1190 Vienna, Austria \\ 4 Department of Botany \& Microbiology, College of Science, King Saud University, Riyadh 11451, Saudi Arabia; \\ tdawoud@ksu.edu.sa \\ * Correspondence: hojjat_pashazadeh@yahoo.com (H.P.); cgalanakis@chemlab.gr (C.M.G.); \\ Tel.: +90-553-665-3055 (H.P.)
}

check for

updates

Citation: Pashazadeh, H.; Zannou, O.; Ghellam, M.; Koca, I.; Galanakis, C.M.; Aldawoud, T.M.S. Optimization and Encapsulation of Phenolic

Compounds Extracted from Maize Waste by Freeze-Drying, Spray-Drying, and Microwave-Drying Using Maltodextrin. Foods 2021, 10, 1396. https://doi.org/10.3390/

foods10061396

Academic Editor: Jayani Chandrapala

Received: 18 May 2021

Accepted: 11 June 2021

Published: 16 June 2021

Publisher's Note: MDPI stays neutral with regard to jurisdictional claims in published maps and institutional affiliations.

Copyright: (c) 2021 by the authors. Licensee MDPI, Basel, Switzerland. This article is an open access article distributed under the terms and conditions of the Creative Commons Attribution (CC BY) license (https:/ / creativecommons.org/licenses/by/ $4.0 /)$.
Abstract: Cornsilk is maize waste containing phenolic compounds. In this study, freeze-drying, spray-drying, and microwave-drying techniques were evaluated for the encapsulation of cornsilk's phenolic compounds using maltodextrin as wall material. The results of antioxidant properties showed that freeze-drying was more efficient than microwave-drying and spray-drying techniques. The highest recovery of phenolic compounds was obtained with freeze-drying. The microstructure, DSC, and FTIR data showed that the encapsulation process was effective, and freeze-drying was the best drying technique. The physical properties of the microparticles greatly changed with the drying techniques. This study revealed that the phenolic compounds of the cornsilk extract can be successfully encapsulated and valorized.

Keywords: antioxidant activity; phenolic compounds; cornsilk; encapsulation techniques

\section{Introduction}

Nowadays, the world faces challenging crises related to health, demography, and nutrition, which require innovative and sustainable solutions. New sources of food and bioactive compounds are being investigated as adequate solutions for health and nutrition. Food bioactives were reported to reinforce the immune system against COVID-19 disease and promote human health [1]. They can help prevent many diseases, including cancers, coughing, inflammatory, cardiovascular, and oxidative stress diseases [2]. The phenolic compounds are one of the most popular bioactive compounds that have a wide range of biological functions and are used for food formulations and pharmaceutical industries [3,4]. The phenolic compounds are widely found in plants, fruits, and wastes. While seeking health and nutrition solutions, the valorization of food wastes for the recovery of phenolic compounds became imperative.

Although bioactives, mainly phenolic compounds, exhibited numerous beneficial effects, they are chemically unstable in neutral $\mathrm{pH}$ environments and when exposed to oxygen $[5,6]$. Furthermore, the chemical structure of phenolic compounds counts unsaturated bonds, which may change the structure and functions of the original compound when exposing to light, oxygen, heat, enzymatic activity, and water [7-9]. Thus, encapsulation techniques were developed to protect the phenolic compounds and improve their bioavailability. Moreover, the encapsulation process can also prevent unwanted taste and odor and extend the shelf-life and usages of phenolic compounds [10,11]. The encapsulation process consists of rendering the bioactive compounds in a solution of wall material, followed by 
drying [12]. The efficiency of encapsulation depends on the coating material and drying techniques $[13,14]$ and the solution homogeneity. Additionally, the optimum concentration of the active compounds, the release mechanism, the final particle size, density, stability requirements, and cost constraints are other essential features to be taken into account [3]. Many coating materials are used for the microencapsulation, including maltodextrin, gum arabic, pectin, proteins, lipids, cyclodextrins, chitosan, and xanthan their combination. These materials' efficacy depends on the preparation parameters of emulsion and features of the targeted compounds $[9,14]$.

Cornsilk is the byproduct of maize (Zea maize L.), which is discarded after taking the corn. In ancient times, cornsilk was used in traditional medicine to treat kidney problems [15]. It was also reported to reduce hyperglycemia by incrementing insulin and recovering the beta-cells and demonstrated diuretic and kaliuretic properties at specific doses $[15,16]$. It has shown antioxidant activity $[15,17]$, antimicrobial, and antidepressant properties $[15,16]$. Cornsilk has been used to treat cystitis, edema, gout, rheumatoid, and arthritis $[16,18]$. Cornsilk has proven beneficial effects in reducing obesity $[19,20]$ and protecting against radiation-induced oxidative stress [21]. In addition, the cornsilk extract is anticancer since it induced apoptosis via the ROS-mediated mitochondrial pathway in MCF-7 cells [22]. These biological activities rely on bioactive compounds such as alkaloids, steroids, flavonoids, phenolic acids, and terpenoids that cornsilk contained [16,23-25].

Corn is the third most-produced cereal crop globally after wheat and rice [26] and consumed boiled and grilled or used to make flour, starch, oil, and syrup. The processing of corn results in a high amount of cornsilk, which is not adequately valorized. It would be beneficial to find a novel approach in the valorization of cornsilk. The phenolic compounds of cornsilk could be extracted to produce natural food additives using well-studied conventional and emerging technologies [27-29].

The recovered phenolic compounds could find different applications in food, cosmetics, and pharmaceutical industries. However, the investigation of their encapsulation and product formation is also critical to ensure their functionality [30]. To this end, the present study considers the optimization of phenolic compound extraction from cornsilk and its encapsulation with maltodextrin using freeze-drying, spray-drying, and microwave-drying.

\section{Material and Methods}

\subsection{Plant Material}

The maize was collected from a field in Samsun/Turkey during the October 2020 season. The cornsilk was separated, washed and stored at $-20^{\circ} \mathrm{C}$ (Figure 1).

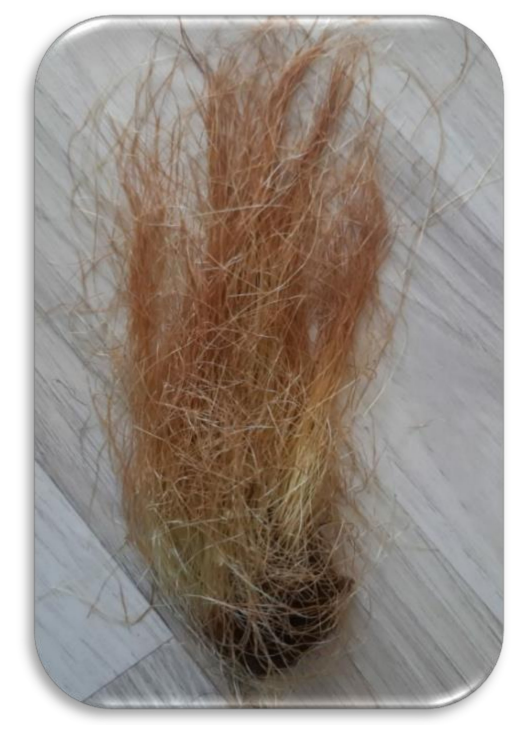

Figure 1. Cornsilk collected from maize (Zea mays Intendata). 


\subsection{Chemical and Reagents}

2,4,6-Tris(2-pyridyl)-1,3,5-triazine (TPTZ), 2,2-Diphenyl-1-Picrylhydrazyl (DPPH), 6hydroxy 2,5,7,8-tetramethylchroman-2-carboxylic acid (Trolox), hydrochloric acid ( $\mathrm{HCl}$, $37 \%)$, methanol $(99,8 \%)$, acetone, sodium nitrite, sodium hydroxide Folin-Ciocalteau reagent, maltodextrin and standards were purchased from Sigma-Aldrich (St. Louis, MO, USA). Gallic acid and sodium carbonate from taken from Riedel-de Haen. Sodium acetate and glacial acetic acid were taken from Carlo Erba. Aluminum chloride and iron chloride were purchased from Merck.

\subsection{Obtaining Cornsilk Extract}

A predefined amount of cornsilk was mixed with $100 \mathrm{~mL}$ of distilled water. The mixtures were extracted in a water bath (Nuve, ST 30) at different times and temperatures. Afterward, the extracts were filtered and diluted adequately for further analyses.

\subsection{Optimization Design}

The extraction parameters such as solid load (amount of sample in g), time (min), and temperature $\left({ }^{\circ} \mathrm{C}\right)$ were optimized to provide the highest yield of total phenolic content (TPC), total flavonoid content (TFC), ferric reducing antioxidant power (FRAP), and DPPH radical scavenging activity (DPPH). The optimization was carried out using the threelevel central composite design (Design expert software 11.0). The solid load, time, and temperature were assigned to the coded variables of $X_{1}, X_{2}$, and $X_{3}$, respectively (Table 1 ). The combinations of the solid load $(0.13,0.5,1,1.5$ and $1.87 \mathrm{~g})$, time $(8.04,30,60,90$ and $111.96 \mathrm{~min})$, and temperature $\left(25.36,40,60,80\right.$, and $\left.94.64{ }^{\circ} \mathrm{C}\right)$ generated 17 experimental points, counting three replicates at the central point. TPC, TFC, FRAP, and DPPH radical scavenging activity values were the responses $(Y)$ (Table 2). The experimental data fitted to the polynomial model in Equation (1):

$$
Y=\beta_{0}+\sum_{n=1}^{3} \beta_{i} X_{i}+\sum_{i=-}^{3} \beta_{i i} X_{i i}+\sum_{i=1}^{2} \sum_{j=i+1}^{3} \beta_{i j} X_{i} X_{j}
$$

where $X_{i}$ and $X_{j}$ are the coded independent variables, $\beta_{i j}, \beta_{i i}$, and $\beta_{i}$ interactive, quadratic, and linear coefficients, respectively, $\beta$ is the model intercept, and $Y$ is the predicted response.

Table 1. Coded and actual values of independent variables.

\begin{tabular}{cccc}
\hline \multirow{2}{*}{ Coded Values } & \multicolumn{3}{c}{ Actual Values } \\
\cline { 2 - 4 } & Solid Load $\left.\mathbf{X}_{\mathbf{1}}\right)$ & Time $\left(\mathbf{X}_{\mathbf{2}}\right)$ & Temperature $\left(\mathbf{X}_{\mathbf{3}}\right)$ \\
\hline-1.73 & 0.13 & 8.04 & 25.36 \\
-1 & 0.5 & 30 & 40 \\
0 & 1 & 60 & 60 \\
1 & 1.5 & 90 & 80 \\
1.73 & 1.87 & 111.73 & 94.64 \\
\hline
\end{tabular}

\subsection{Total Phenolic Content (TPC)}

The TPC was determined using Folin-Ciocalteu method as described in Zannou and Koca [31]. The absorbance was read at $760 \mathrm{~nm}$ using a UV- spectrometer (Thermo Spectronic) and compared to a standard curve as gallic acid equivalent (mg GAE/g). 
Table 2. Actual units, coded units and responses of central composite design.

\begin{tabular}{|c|c|c|c|c|c|c|c|}
\hline \multirow{2}{*}{ Run } & \multicolumn{3}{|c|}{ Coded Values } & \multicolumn{4}{|c|}{ Responses } \\
\hline & $X_{1}$ & $X_{2}$ & $X_{3}$ & TPC, mg GAE/g & TFC, mg ECE/g & DPPH, mmol TE/g & FRAP, mmol ISE/g \\
\hline 1 & 0 & 0 & $-1,73$ & $20.31 \pm 1.52$ & $2.19 \pm 0.012$ & $31.83 \pm 3.70$ & $60.44 \pm 0.84$ \\
\hline 2 & -1 & 1 & -1 & $24.27 \pm 1.17$ & $3.09 \pm 0.33$ & $52.81 \pm 1.85$ & $80.14 \pm 1.52$ \\
\hline 3 & -1 & -1 & -1 & $20.61 \pm 0.31$ & $2.78 \pm 0.06$ & $40.91 \pm 4.84$ & $72.94 \pm 2.20$ \\
\hline 4 & 1 & 1 & -1 & $28.71 \pm 1.66$ & $3.44 \pm 0.04$ & $49.73 \pm 1.33$ & $68.00 \pm 1.35$ \\
\hline 5 & 1 & -1 & -1 & $19.16 \pm 1.01$ & $2.27 \pm 0.042$ & $45.02 \pm 4.08$ & $58.39 \pm 0.79$ \\
\hline 6 & 0 & 1.73 & 0 & $33.84 \pm 1.51$ & $5.03 \pm 0.33$ & $75.80 \pm 4.27$ & $104.17 \pm 6.79$ \\
\hline 7 & 0 & 0 & 0 & $23.05 \pm 1.38$ & $4.39 \pm 0.06$ & $75.20 \pm 1.14$ & $101.29 \pm 2.72$ \\
\hline 8 & 0 & 0 & 0 & $32.08 \pm 0.69$ & $4.44 \pm 0.01$ & $65.32 \pm 1.56$ & $86.39 \pm 1.53$ \\
\hline 9 & 0 & -1.73 & 0 & $23.84 \pm 0.41$ & $3.51 \pm 0.55$ & $45.35 \pm 0.71$ & $70.53 \pm 3.57$ \\
\hline 10 & 0 & 0 & 0 & $31.69 \pm 0.27$ & $4.88 \pm 0.08$ & $74.59 \pm 2.28$ & $111.38 \pm 6.13$ \\
\hline 11 & -1.73 & 0 & 0 & $46.65 \pm 4.79$ & $4.89 \pm 0.06$ & $89.45 \pm 1.59$ & $178.06 \pm 5.14$ \\
\hline 12 & 1.73 & 0 & 0 & $26.34 \pm 3.03$ & $3.01 \pm 0.47$ & $50.14 \pm 1.98$ & $76.42 \pm 2.18$ \\
\hline 13 & 1 & 1 & 1 & $38.13 \pm 0.18$ & $5.27 \pm 0.07$ & $60.62 \pm 0.57$ & $101.32 \pm 1.47$ \\
\hline 14 & -1 & 1 & 1 & $50.82 \pm 3.49$ & $5.69 \pm 0.32$ & $101.99 \pm 2.56$ & $146.35 \pm 1.36$ \\
\hline 15 & 1 & -1 & 1 & $40.35 \pm 1.29$ & $6.09 \pm 0.20$ & $60.76 \pm 1.52$ & $108.84 \pm 0.00$ \\
\hline 16 & -1 & -1 & 1 & $37.08 \pm 3.60$ & $7.20 \pm 0.24$ & $112.88 \pm 3.13$ & $155.48 \pm 6.13$ \\
\hline 17 & 0 & 0 & 1.73 & $47.97 \pm 5.13$ & $6.35 \pm 0.78$ & $90.33 \pm 0.57$ & $133.00 \pm 7.02$ \\
\hline
\end{tabular}

$\mathrm{X}_{1}=$ Solid load $\mathrm{X}_{2}=$ Time; $\mathrm{X}_{3}=$ Temperature; TPC = Total Phenolic Content; TFC = Total flavonoid content; DPPH = DPPH Radical Scavenging Activity; FRAP = Ferric Reducing Antioxidant Power.

\subsection{Total Flavonoid Content (TFC)}

The TFC was determined using the protocol [31]. The absorbance was read at $510 \mathrm{~nm}$, and TFC was calculated following the calibration curve of epigallocatechin. The results were given as mg epigallocatechin equivalents (ECE) per $\mathrm{g}$.

\subsection{DPPH Radical Scavenging Activity Assay}

The DPPH assay was carried out following the method of Zannou et al. [32]. The mixture was placed in the dark for $1 \mathrm{~h}$ at room temperature, followed by the absorbance recording at $517 \mathrm{~nm}$. The DPPH solution was used as a control, and the scavenging ratio was calculated with Equation (2).

$$
\text { Reduction }(\%)=\left(\frac{A_{c}-A_{s}}{A_{c}}\right) \times 100
$$

where $A_{\mathcal{C}}$ is the absorbance of the control and $A_{s}$ is the absorbance of extract.

\subsection{Ferric Reducing Antioxidant Power (FRAP) Assay}

FRAP assay performed according to the procedure of Zannou et al. [32] The FRAP values of the extracts were calculated from a calibration curve using $\mathrm{FeSO} 4$ as standard. The results were given as mmol FeSO4 equivalents (mmol ISE/g).

\subsection{Encapsulation Process}

For the encapsulation of the phenolic compounds of maize byproduct aqueous extracts, three techniques (freeze-drying, spray-drying, and microwave-drying) were used and compared. Maltodextrin (4.0-7.0 DE) was used as a coating agent. Maltodextrin and extract mixture was prepared by mixed $10 \mathrm{~g}$ of maltodextrin with $90 \mathrm{~g}$ of cornsilk aqueous extract. The mixture was heated at $60{ }^{\circ} \mathrm{C}$ for $1 \mathrm{~h}$ and then subjected to ultraturax at $11,000 \mathrm{rpm}$ for $5 \mathrm{~min}$. The spray drying was performed using a Buchi mini spray dryer B-290 (Noble Park, VIC, Australia) as described in [33]. The freeze-drying was carried out by initially frozen the samples using liquid nitrogen and then freeze-dried for $48 \mathrm{~h}$ (FD3 freeze dryer, Thomas Australia Pty. Ltd., Seven Hills, NSW, Australia) [33]. The microwave drying was performed in a domestic microwave oven (Vestel, Turkey) at microwave power intensity of $750 \mathrm{~W}$ for $10 \mathrm{~min}$, selected based on the preliminary experiments. 


\subsection{Production Yield}

The production yield $(P Y)$ is the percentage of the concentration ratio in powder to the total concentration in the extract. PY of TPC, TFC, DPPH radical scavenging and FRAP was determined with Equation (3).

$$
P Y=\frac{\text { Concentration in powder }}{\text { Total concentration in the extract }} \times 100
$$

\subsection{Surface Phenolic Content and Efficiency of Phenolic Compounds}

The surface phenolic content was determined by the method of Cilek et al. [14]. The encapsulation efficiency of microcapsules' phenolic content was calculated according to Equation (4).

$$
E E=\frac{\text { Total phenolic content }- \text { Surface phenolic content }}{\text { Total phenolic content }} \times 100
$$

\subsection{Physico-Chemical Characteristics}

The moisture content was measured with an oven at $70{ }^{\circ} \mathrm{C}$ for $24 \mathrm{~h}$. The solubility was determined according to the method used by Fazaeli et al. [34] The bulk density and tapped density were determined according to [35]. Carr index was calculated from the bulk and tapped densities of the powders as expressed in Equation (5).

$$
\text { Carr index }=\frac{\text { Tapped density }- \text { Bulk density }}{\text { Tapped density }}
$$

\subsection{Microstructure Analysis}

The microstructure analysis was performed using a scanning electron microscope (SEM, JEOL JSM-7001F). A small specimen was briefly taken from the samples and attached to a stainless stub with double sticky tape. The assembly was then immediately sputtered with a gold/palladium target $(60 / 40)$ in approximately $10 \mathrm{~nm}$ using a sputter coater, functioning with argon and plasma current for $2 \mathrm{~min}$. The images were recorded at an acceleration voltage of $10 \mathrm{kV}$ and $15 \mathrm{kV}$.

\subsection{Differential Scanning Calorimetry (DSC) Analysis}

The differential scanning calorimeter (New Castle, DE; TA Instrument 2010) was used for the calorimetric measurements and calibrated with indium. The calorimetric scans' temperature range varied from 10 to $60^{\circ} \mathrm{C}$, under nitrogen flow. The scan rate was set to $5{ }^{\circ} \mathrm{C} \mathrm{min}^{-1}$. The Tm and $\Delta \mathrm{H}$ were determined from the thermograms by the Universal 4.0 C. Software.

\subsection{Fourier Transformed Infrared (FTIR) Analysis}

FTIR analysis was carried out according to [32] using an FTIR spectrometer (Perkin Elmer, Spectrum-Two, USA, PEService 35).

\subsection{LC/MS/MS Analysis}

The phenolic compounds were determined using liquid chromatography coupled to a mass spectrometer detector (LC-MS/MS, Shimadzu LC-MS 8040) via electrospray ionization (ESI) and two pumps (LC-30 AD), a column oven (CTO-10AS VP), an autosampler (SIL-30AC) and a degassing unit (DGU-20A 3R), according to Zannou et al. [36] The phenolic compounds were identified based on their elution time and quantified from their peak area. The identified compounds were quantified using a mixture of external standards (protocatechuic aldehyde, protocatechuic acid, gallic acid, catechin, vanilin, $\rho$-cumaric acid, caffeic acid, ferulic acid, 4-hydroxy benzoic acid, salicylic acid, ellagic acid and quercetin) at different concentrations. 


\subsection{Data Analysis}

The Design-Expert software 9.0 (Trial version, Stat-Ease Inc., Minneapolis, MN, USA) was used to design the optimization process and to generate the models and $3 \mathrm{D}$ graphics. The ANOVA of response surface methodology was applied for the statistical significance. The coefficient of determination $\left(R^{2}\right)$, adjusted coefficient of determination (adj. $R^{2}$ ), coefficient of variation (CV), and Fisher's test value (F-value) were used for the validation of the models. The models and terms were considered significant at $p<0.05$. The optimum conditions were determined based on the desirability function. Other analyses were carried out in three replicate, the one-way ANOVA with posthoc Duncan's test was applied (SPSS, version 21) and the results were considered at $p \leq 0.05$.

\section{Results and Discussion}

\subsection{RSM Results}

\subsubsection{Model Analysis}

The optimization process was performed on the extraction conditions of solid load (amount of sample in $\mathrm{g}$ ), time $(\mathrm{min})$, and temperature $\left({ }^{\circ} \mathrm{C}\right)$ to have the highest yield of TPC, TFC, FRAP, and DPPH radical scavenging activity. The coded and responses results of the experimental runs were shown in Table 2. The responses were ranges of 20.30-50.82 mg GAE/g, 2.19-7.20 mg ECE/g, 31.83-112.83 mmol TE/g, and 58.39-178.06 mmol ISE/g for TPC, TFC, DPPH radical scavenging activity, and FRAP values, respectively. Nurhanan and Wan Rosli [17] have reported ranges of 6.70-101.99 mg GAE/g for TPC and 0.66-9.26 mg catechin equivalent/g for TFC in cornsilk extracted with water, methanol, ethanol, and ethyl acetate. Ebrahimzadeh et al. [37] have reported $118.94 \mathrm{mg} \mathrm{GAE} / \mathrm{g}$ and $58.22 \mathrm{mg}$ quercetin equivalent/g for TPC and TFC, respectively. Our results were higher than those reported previously. The highest findings detected in the cornsilk studied in this study might be related to corn species, production, and extraction analysis conditions. During the RSM process, the highest TPC was found at run $14\left(0.5 \mathrm{~g}, 90 \mathrm{~min}\right.$, and $\left.80^{\circ} \mathrm{C}\right)$ and the highest TFC at run $16\left(0.5 \mathrm{~g}, 30 \mathrm{~min}\right.$, and $\left.80^{\circ} \mathrm{C}\right)$. The most increased DPPH radical scavenging activity and FRAP were found at run $16\left(0.5 \mathrm{~g}, 30 \mathrm{~min}\right.$, and $\left.80^{\circ} \mathrm{C}\right)$ and run $11(0.13 \mathrm{~g}, 60$ $\mathrm{min}$, and $60^{\circ} \mathrm{C}$ ). It was observed that the dependent variables responded differently with each combination of independent variables. Such observation was observed previously during the optimization for the extraction conditions $[31,38]$. The significance of regression coefficients of polynomial models was set at $p<0.05$. The reduced second-order models of coded units were stepwise determined and expressed as:

$$
\begin{gathered}
\text { TPC }=28.94-2.97 X_{1}+3.00 X_{2}+8.68 X_{3}-1.26 X_{1} X_{2}-1.55 X_{1} X_{3} \\
-0.2131 X_{2} X_{3}+2.37 X_{1}^{2}-0.1785+1.59 X_{3}^{2} \\
T F C=4.57-0.35 X_{1}+0.13 X_{2}+1.42 X_{3}+0.19 X_{1} X_{2}-0.17 X_{1} X_{3}-0.48 X_{2} X_{3} \\
-0.15 X_{1}^{2}-0.04 X_{2}^{2}-0.04 X_{3}^{2} \\
\text { DPPH radical scavenging }=71.70-11.47 X_{1}+4.17 X_{2}+17.79 X_{3}+0.45 X_{1} X_{2} \\
-11.82 X_{1} X_{3}-3.45 X_{2} X_{3}-0.30 X_{1}^{2}-3.37 X_{2}^{2}-3.20 X_{3}^{2} \\
F R A P=99.68-21.03 X_{1}+4.17 X_{2}+25.58 X_{3}+0.50 X_{1} X_{2}-8.12 X_{2} X_{3} \\
-4.18 X_{2} X_{3}+8.27 X_{1}^{2}-5.03 X_{2}^{2}-1.91 X_{3}^{2}
\end{gathered}
$$

The results of ANOVA of the responses given by RSM were assembled in Table 3. The model TPC is significant $(p<0.0185)$ and presented relatively higher $R^{2}(0.8741)$, adjusted $R^{2}(0.7121)$, and adequate precision (7.5136). This adequate precision referred to the desired signal-to-noise ratio, which means that the model can be used to navigate the design space. The lack of fit (F-value 1.19) is insignificant due to the pure error, indicating that the model is well fitted. For the model generated for TFC, the model is significant $(p<0.0025)$ and characterized by higher $R^{2}(0.9324)$, adjusted $R^{2}(0.8455)$, predicted $R^{2}(0.5045)$, and adequate precision (11.1069). Its lack of fit is non-significant with F-value $6.11(p<0.1466)$. Thus, the model had a good fit. 
Table 3. Results of ANOVA of the reduced models.

\begin{tabular}{|c|c|c|c|c|c|c|c|c|c|c|c|c|}
\hline & SS & $\begin{array}{c}\text { TPC } \\
\text { F-Value }\end{array}$ & $p$-Value & SS & $\begin{array}{c}\text { TFC } \\
\text { F-Value }\end{array}$ & $p$-Value & SS & $\begin{array}{c}\text { DPPH } \\
\text { F-Value }\end{array}$ & $p$-Value & SS & $\begin{array}{c}\text { FRAP } \\
\text { F-value }\end{array}$ & $p$-Value \\
\hline Model & 1434.39 & 5.40 & 0.0185 & 32.81 & 10.73 & 0.0025 & 7954.31 & 17.89 & 0.0005 & $18,013.62$ & 8.39 & 0.0052 \\
\hline $\mathrm{X}_{1}$ & 123.65 & - & - & 1.74 & - & - & 1841.40 & 37.27 & 0.0005 & 6190.97 & 25.95 & 0.0014 \\
\hline$X_{2}$ & 126.37 & - & - & 0.23 & - & - & 243.05 & - & - & 243.74 & - & - \\
\hline$x_{3}$ & 1055.32 & 35.74 & 0.0006 & 28.21 & 83.03 & $<0.0001$ & 4431.78 & 89.69 & $<0.0001$ & 9164.05 & 38.42 & 0.0004 \\
\hline $\mathrm{X}_{1} \mathrm{X}_{2}$ & 12.69 & - & - & 0.30 & - & - & 1.59 & - & - & 2.00 & - & - \\
\hline$X_{1} x_{3}$ & 19.25 & - & - & 0.24 & - & - & 1116.95 & 22.61 & 0.0021 & 528.01 & - & - \\
\hline$X_{2} X_{3}$ & 0.3632 & - & - & 1.83 & - & - & 95.45 & - & - & 140.06 & - & - \\
\hline $\mathrm{X}_{1} \mathrm{X}_{1}$ & 68.60 & - & - & 0.27 & - & - & 1.09 & - & - & 832.95 & - & - \\
\hline$X_{2} X_{2}$ & 0.3887 & - & - & 0.02 & - & - & 138.57 & - & - & 308.76 & - & - \\
\hline$x_{3} x_{3}$ & 30.73 & - & - & 0.02 & - & - & 125.09 & - & - & 44.43 & - & - \\
\hline Residual & 206.67 & & & 2.38 & & & 345.87 & & & 1669.69 & & \\
\hline $\begin{array}{c}\text { Lack of } \\
\text { Fit }\end{array}$ & 154.61 & 1.19 & 0.5159 & 2.23 & 6.11 & 0.1466 & 284.50 & 1.85 & 0.3864 & 1353.72 & 1.71 & 0.4081 \\
\hline $\begin{array}{l}\text { Pure } \\
\text { error }\end{array}$ & 52.06 & & & 0.15 & & & 61.38 & & & 315.97 & & \\
\hline Total & 1641.06 & & & 35.18 & & & 8300.18 & & & $19,683.31$ & & \\
\hline $\mathrm{R}^{2}$ & 0.8741 & & & 0.9324 & & & & & & 0.9152 & & \\
\hline $\operatorname{Adj} R^{2}$ & 0.7121 & & & 0.8455 & & & & & & 0.8061 & & \\
\hline $\begin{array}{c}\text { Pred } R^{2} \\
\text { Adeq }\end{array}$ & 0.1696 & & & 0.5045 & & & & & & 0.4370 & & \\
\hline $\begin{array}{l}\text { Preci- } \\
\text { sion }\end{array}$ & 7.5136 & & & 11.1069 & & & & & & 9.3927 & & \\
\hline C.V. \% & 16.95 & & & 13.29 & & & & & & 15.33 & & \\
\hline
\end{tabular}

- = Insignificant terms at $p<0.05 ; \mathrm{X}_{1}=$ Solid load; $\mathrm{X}_{2}=$ Time; $\mathrm{X}_{3}=$ Temperature; TPC = Total Phenolic Content; TFC = Total flavonoid content; DPPH = DPPH Radical Scavenging Activity; FRAP = Ferric Reducing Antioxidant Power.

The model of DPPH radical scavenging is significant $(p<0.0005)$, exhibiting higher $\mathrm{R}^{2}$ (0.9583), adjusted $R^{2}$ (0.9048), predicted $R^{2}$ (0.7158), and adequate precision (13.8924). The predicted $R^{2}$ is in reasonable agreement with the Adjusted $R^{2}$, and the sufficient accuracy of 13.892 indicates that the model can be used to navigate the design space. The lack of fit (F-value 1.85) is not significant, implying that the model is a good fit. The model developed for FRAP is significant with F-value $(p<0.0052)$ and presented greater $R^{2}$ (0.9152) and adjusted $R^{2}(0.8061)$. The adequate precision of 9.3927 is desirable, and the model is sufficient for the navigation of the design space. The lack of fit is insignificant (F-value 1.71), suggesting that the model had a desirable fit.

\subsubsection{RSM-Effects of Independent Variables on the Responses}

The effects of different terms of independent variables on the responses were given in Table 3. The linear terms of solid load and extraction time had no significant impact on TPC and TFC, respectively, while the linear terms of temperature displayed a significant effect. Likewise, the linear terms of solid ratio and temperature presented significant DPPH radical scavenging and FRAP results. No quadratic and interaction units showed substantial impacts on the responses. Previously, it was demonstrated that the RSM linear and quadratic terms react differently depending on the samples' intrinsic characteristics, many independent variables, and analysis conditions [32,38].

The 3D graphics showing the impacts of combining the independent variables on the responses were given in Figures 2-5. As can be seen, the TPC augmented greatly when increasing the extraction time and temperature. Similarly, Nurraihana et al. [39] have reported that the TPC increased when increasing the extraction time. The solid-to-liquid ratio exhibited a moderate effect on TPC, where the TPC decreased from 0.13 to $1.50 \mathrm{~g}$ and then increased. 

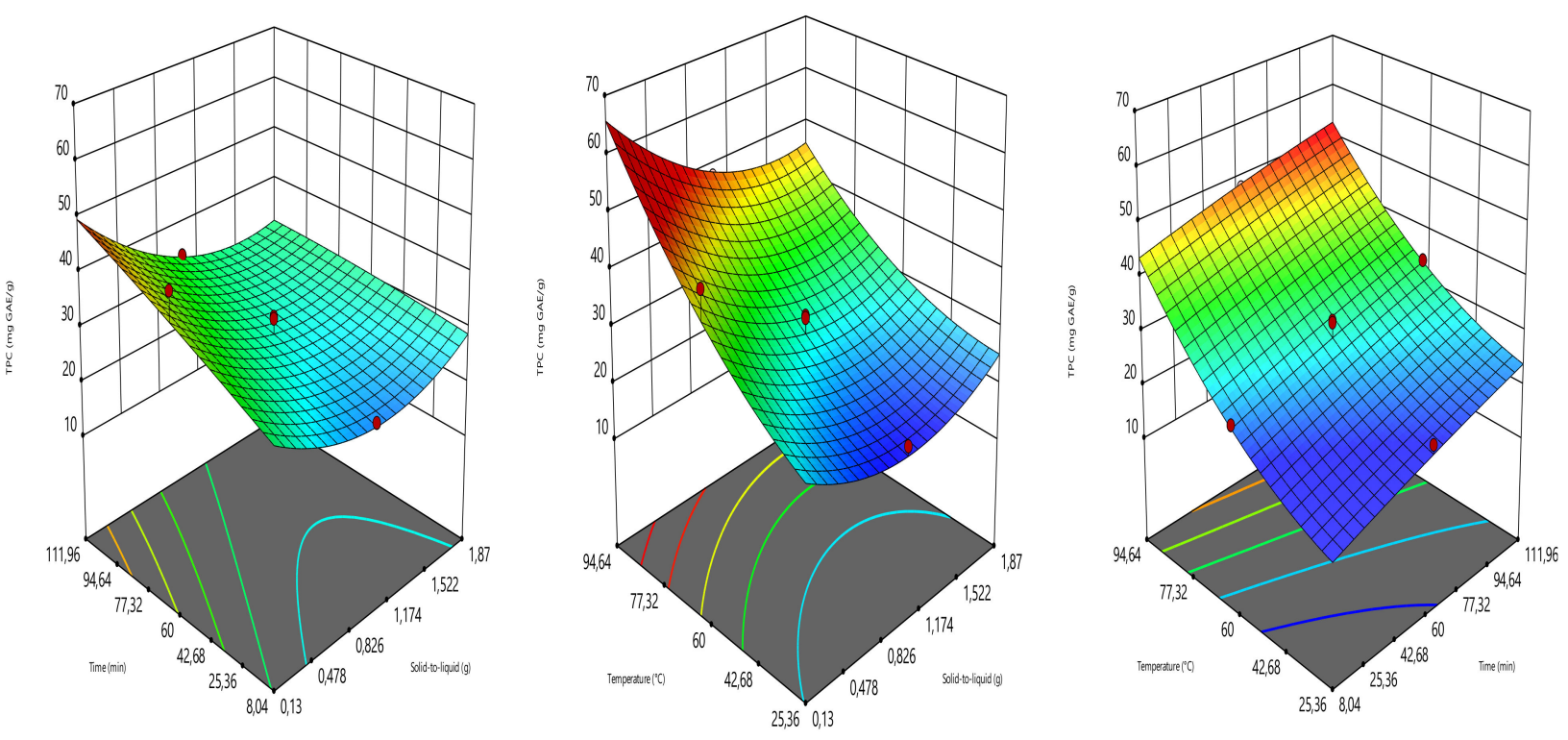

Figure 2. Three-dimensional graphics showing the effects of the independent variables on TPC.

For the TFC, the different combinations of the independent variables responded diversely (Figure 3). In the combination of decoction time and solid-to-liquid ratio, the decoction time did not show a significant effect on TFC, while the solid-to-liquid ratio had a significant effect on this response. The TFC showed the highest values at $0.13-1.17 \mathrm{~g}$ and then decreased. In the combination of temperature and solid-to-liquid ratio, the solidto-liquid ratio was almost indifferent while the temperature-induced a strong increase in TFC when augmenting. Whereas the increase in the combination of temperature and time exhibited a great increase in TFC.
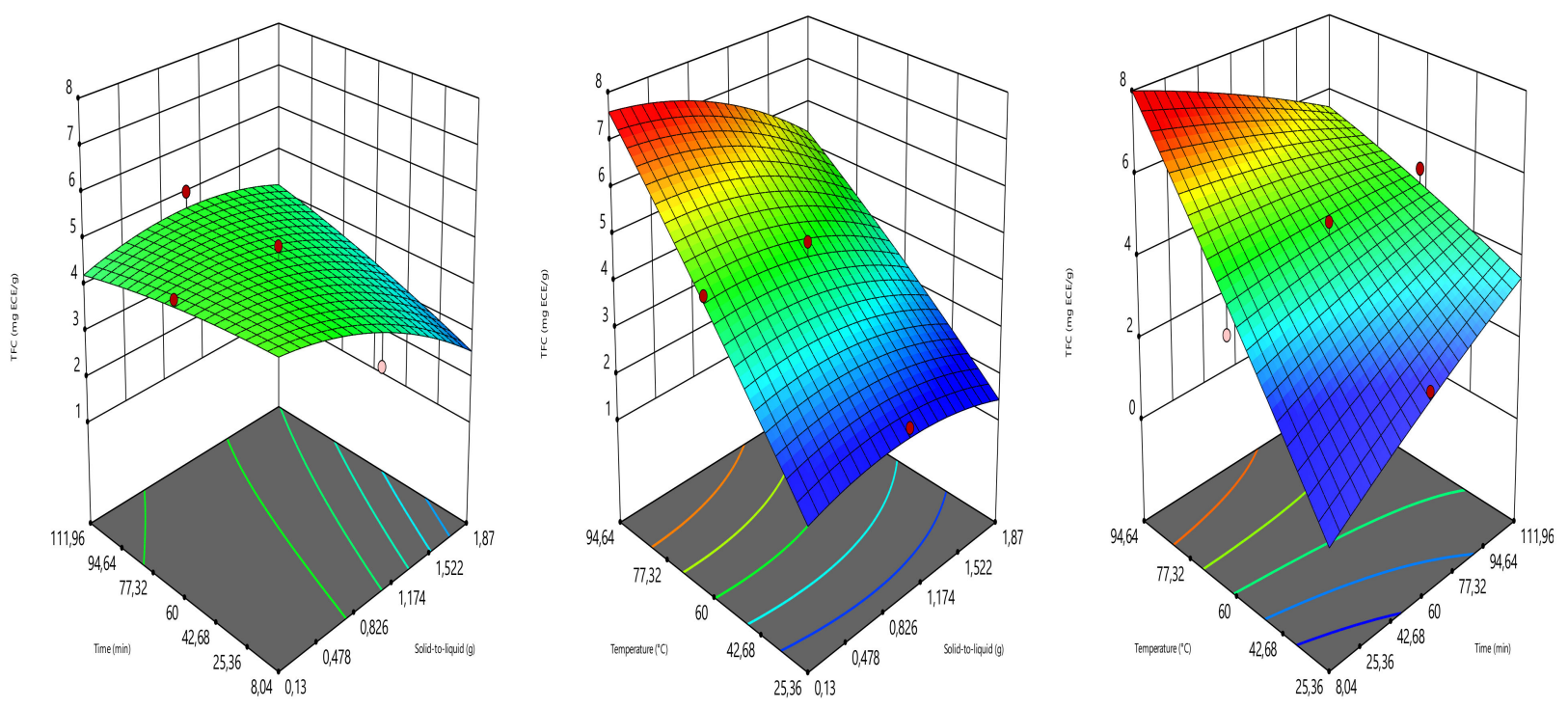

Figure 3. Three-dimensional graphics showing the effects of the independent variables on TFC.

As can be seen in Figure 4, the temperature and decoction time have mostly influenced the response DPPH. The amount of this latter increased with the increase in the temperature and decoction time, while almost with solid-to-liquid ratio. Similarly, Nurraihana et al. [39] have reported that the DPPH values increased with the increase the extraction time. 

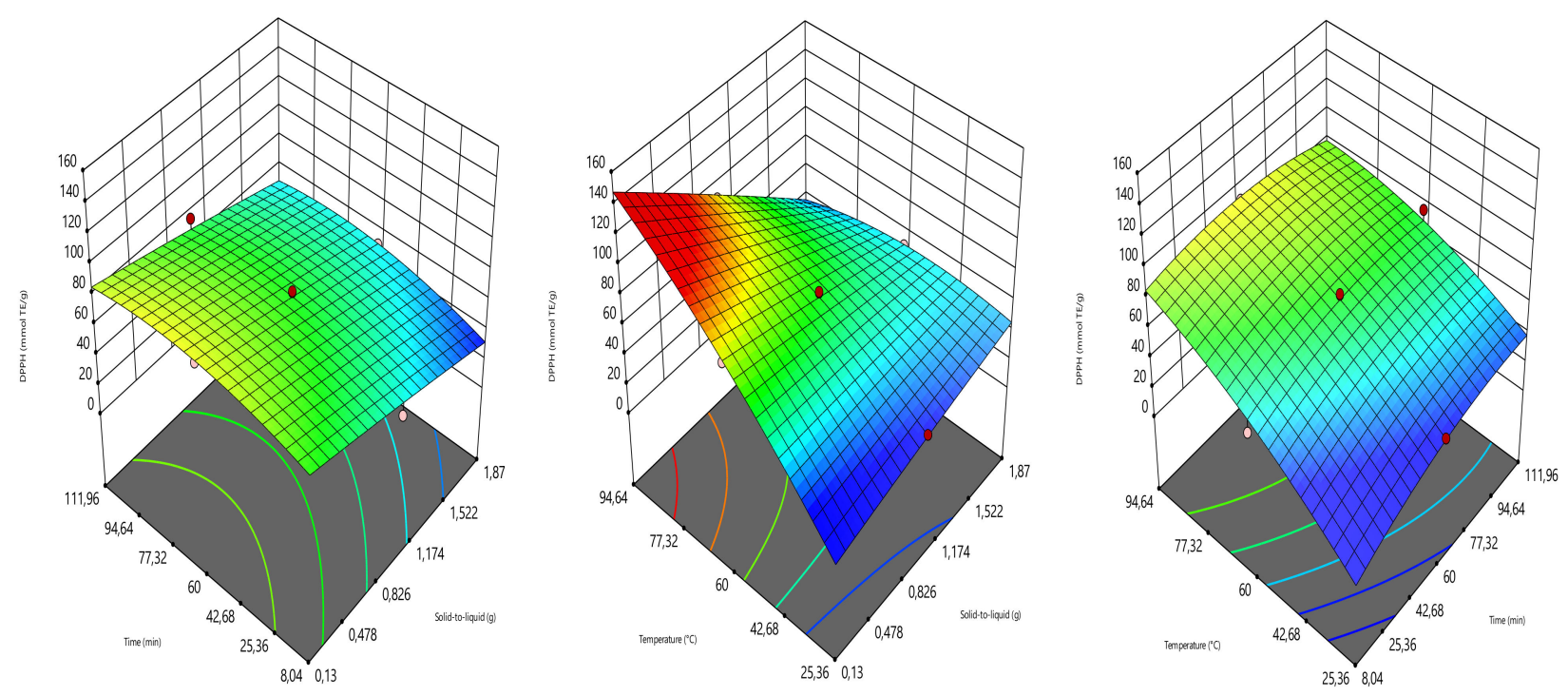

Figure 4. Three-dimensional graphics showing the effects of the independent variables on DPPH.

The independent variables have greatly influenced the response FRAP (Figure 5). The increase in temperature and decoction time induced the increase in FRAP. However, FRAP showed a decrease at solid-to-liquid ratio ranged from 0.13 to $1.52 \mathrm{~g}$ and then increased.
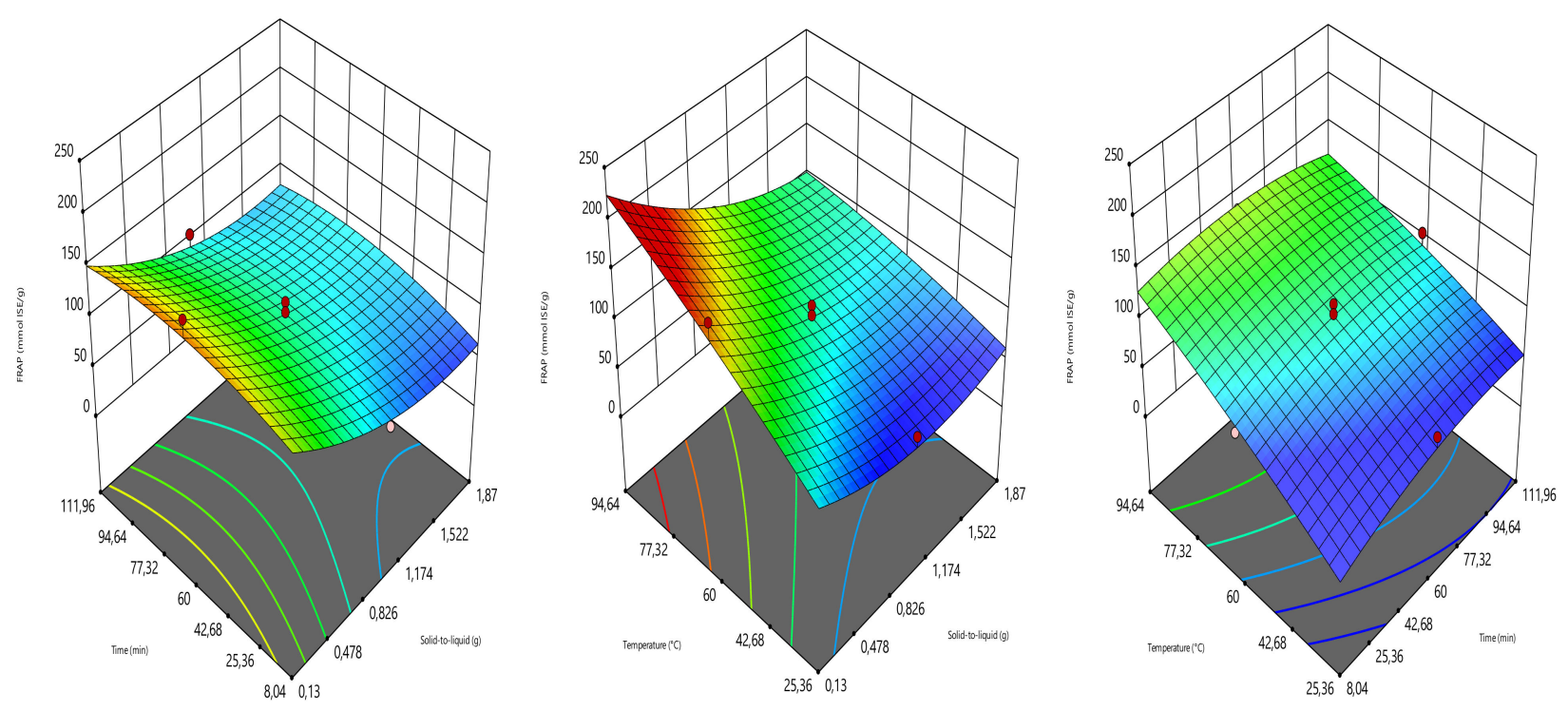

Figure 5. Three-dimensional graphics showing the effects of the independent variables on FRAP.

\subsubsection{Multi-RSM}

The application of the desirability function determined the optimum conditions to have the maximum responses. The optimum extraction conditions at desirability 0.871 were $0.5 \mathrm{~g}$, $62.10 \mathrm{~min}$, and $80{ }^{\circ} \mathrm{C}$ giving $46.39 \mathrm{mg} \mathrm{GAE} / \mathrm{g}, 6.29 \mathrm{mg} \mathrm{ECE} / \mathrm{g}, 109.28 \mathrm{mmol} \mathrm{TE} / \mathrm{g}$, and $160.72 \mathrm{mmol}$ ISE/g for TPC, TFC, DPPH radical scavenging, and FRAP, respectively. Further analyses were performed at the optimum conditions for confirmation and the experimental results were found close to the predicted values as $58.87 \pm 1.38 \mathrm{mg} \mathrm{GAE} / \mathrm{g}$, $6.64 \pm 0.12 \mathrm{mg} \mathrm{ECE} / \mathrm{g}, 132.63 \pm 1.66 \mathrm{mmol} \mathrm{TE} / \mathrm{g}$, and $172.30 \pm 3.40$ for TPC, TFC, DPPH radical scavenging, and FRAP, respectively. The encapsulation process was performed at the optimum experimentation conditions. 


\subsection{Phytochemical and Antioxidant Features of Extract and Powders}

Under these conditions, the experimental results were $58.87 \pm 1.38 \mathrm{mg} \mathrm{GAE} / \mathrm{g}$, $6.64 \pm 0.12 \mathrm{mg} \mathrm{ECE} / \mathrm{g}, 132.63 \pm 1.66 \mathrm{mmol} \mathrm{TE} / \mathrm{g}$, and $172.30 \pm 3.40$ for TPC, TFC, DPPH radical scavenging, and FRAP, respectively. In contrast, previous studies have reported fewer antioxidant features that can be associated with corn cultivars, cultivation, and analysis conditions $[17,37,39]$. Nine phenolic compounds were identified from cornsilk, and protocatechuic acid $(205.21 \mu \mathrm{g} / \mathrm{g})$ was the most abundant, followed by $\rho$-coumaric acid $(42.67 \mu \mathrm{g} / \mathrm{g})$, caffeic acid $(36.87 \mu \mathrm{g} / \mathrm{g})$, and ferulic acid $(12.11 \mu \mathrm{g} / \mathrm{g})$ (Table 4). Similarly, Aires and Carvalho [40] have found out that the main phenolic compounds in cornsilk collected from Portugal were ferulic acid $(45.2 \mu \mathrm{g} / \mathrm{g})$, followed by chlorogenic acid $(39.9 \mu \mathrm{g} / \mathrm{g})$, caffeic acid $(12.9 \mu \mathrm{g} / \mathrm{g})$, apigenin $(7.4 \mu \mathrm{g} / \mathrm{g})$ and pelargonidin $(2.4 \mu \mathrm{g} / \mathrm{g})$.

Table 4. LC/MS/MS quantification of phenolic compounds identified in extract and powders.

\begin{tabular}{|c|c|c|c|c|c|}
\hline \multirow{2}{*}{ RT } & \multirow{2}{*}{ Phenolic Compounds } & \multicolumn{4}{|c|}{ Concentrations $\mu \mathrm{g} / \mathrm{g}$} \\
\hline & & \multicolumn{2}{|c|}{ Extract Freeze-Drying } & \multirow{2}{*}{$\begin{array}{c}\text { Microwave-Drying } \\
\text { n.d. }\end{array}$} & \multirow{2}{*}{$\begin{array}{c}\text { Spray-Drying } \\
\text { n.d. }\end{array}$} \\
\hline 10.05 & Gallic acid & 1.42 & n.d. & & \\
\hline 12.22 & Protocateuic acid & 205.21 & 152.06 & n.d. & 16.53 \\
\hline 13.16 & $\begin{array}{c}\text { Protocatechuic } \\
\text { aldehyde }\end{array}$ & 1.82 & n.d. & n.d. & 21.51 \\
\hline 13.33 & Catechin & 0.00 & 5.58 & 2.38 & 3.60 \\
\hline 15.18 & Caffeic acid & 36.87 & n.d. & n.d. & 30.19 \\
\hline 15.87 & Vanilin & 1.35 & 17.79 & n.d. & 17.78 \\
\hline 16.91 & $\rho$-cumaric acid & 42.66 & 112.83 & n.d. & 101.30 \\
\hline 17.18 & Ferulic acid & 12.11 & n.d. & n.d. & n.d. \\
\hline 18.03 & $\begin{array}{l}\text { 4-Hydroxy benzoic } \\
\text { acid }\end{array}$ & 1.06 & 6.00 & 5.77 & 23.89 \\
\hline 18.13 & Salicylic acid & 1.25 & 17.32 & 3.61 & 10.32 \\
\hline 19.38 & Ellagic acid & n.d. & n.d. & 13.98 & 7.41 \\
\hline
\end{tabular}

$\mathrm{RT}$ is the retention time; n.d. = not identified.

As can be seen in Table 4, the freeze-drying was the most efficient drying method compared to other drying methods, providing the highest values of protocateuic acid $(152.06 \mu \mathrm{g} / \mathrm{g}), \rho$-cumaric acid $(112.83 \mu \mathrm{g} / \mathrm{g})$, vanilin $(17.79 \mu \mathrm{g} / \mathrm{g})$, salicylic acid $(17.32 \mu \mathrm{g} / \mathrm{g})$ and catechin $(5.58 \mu \mathrm{g} / \mathrm{g})$. These findings were in agreement with Ballesteros et al. [41] who have found out that maltodextrin was the best wall material and freeze-drying the best drying technique for the encapsulation of antioxidant phenolic compounds. Gallic acid and ferulic acid disappeared during the drying processes, while ellagic acid appeared in spray and microwave-dried samples. Catechin and ellagic acid were probably under the detection limit for the extract but they were found in certain powders. Thus, the drying processes differently affected the individual phenolic compounds. Protocatechuic aldehyde, gallic acid, vanillin, salicylic acid, and 4-hydroxybenzoic acid were also identified in the present study as minor phenolic compounds. The extract obtained after the application of RSM displayed a high amount of protocatechuic acid and the freeze-drying protected these compounds better. Protocatechuic acid has great antioxidant activity and salicylic acid is well-known to have analgesic, antipyretic anti-inflammatory properties.

\subsection{Encapsulation Efficiency}

The efficiency of the drying processes (freeze-drying, spray-drying, and microwavedrying) after the encapsulation was evaluated and showed in Table 5 . The best results were achieved using the freeze-drying technique. Under these conditions, the percentage of TPC, TFC, DPPH radical scavenging, and FRAP retained in the encapsulated samples were $98.85 \pm 0.90 \%, 97.95 \pm 4.21 \%, 70.39 \pm 6.20 \%, 82.45 \pm 0.89 \%$, respectively. These results follow those reported previously, where the highest amount of retention of antioxidant activity and phenolic compounds in the encapsulated samples was obtained with freezedrying and $100 \%$ maltodextrin [41]. The freeze-drying was followed by spray-drying 
and microwave-drying processes. Regarding the efficiency of encapsulation, the drying technique was revealed to be the fundamental factor. The efficiency given by the freezedrying method could be partially attributed to the morphological changes occurring in the drying process. The freeze-drying resulted in the sawdust-like shape, which creates a lower surface area/volume ratio. Simultaneously, the spray-drying generates a larger surface area, allowing the phenolic compounds of the surface to alter [41].

Table 5. Productivity yield and efficiency of microencapsulated powders.

\begin{tabular}{|c|c|c|c|c|c|c|}
\hline \multirow[b]{2}{*}{ Treatments } & \multicolumn{6}{|c|}{ Productivity Yield (\%) } \\
\hline & TPC & TFC & DPPH & FRAP & $\begin{array}{c}\text { Surface Phenolic } \\
\text { Content (mg GAE/g) }\end{array}$ & Efficiency (\%) \\
\hline Microwave-drying & $82.29 \pm 0.45 c$ & $71.16 \pm 4.21 b$ & $72.27 \pm 1.77 a$ & $51.07 \pm 089 b$ & $0.7944 \pm 0.21 b$ & $99.83 \pm 0.04 a$ \\
\hline Freeze-drying & $98.85 \pm 0.90 a$ & $97.95 \pm 4.21 \mathrm{a}$ & $70.39 \pm 6.20 a$ & $82.45 \pm 0.89 a$ & $0.9350 \pm 0.07 b$ & $99.84 \pm 0.01 \mathrm{a}$ \\
\hline Spray-drying & $87.39 \pm 0.45 b$ & $76.37 \pm 7.37 \mathrm{~b}$ & $81.03 \pm 7.08 \mathrm{a}$ & $56.30 \pm 3.55 b$ & $1.7844 \pm 0.11 \mathrm{a}$ & $99.65 \pm 0.02 b$ \\
\hline
\end{tabular}

Different letters in the same column mean significant difference at $\mathrm{p} \leq 0.05$.

The surface phenolic contents were low which denoted higher efficiency of the encapsulation of phenolic compounds (Table 5). As can be seen in Table 4, the freeze-drying was the most efficient drying method compared to other drying methods, providing the highest values of protocatechuic acid $(152.06 \mu \mathrm{g} / \mathrm{g}), \rho$-cumaric acid $(112.83 \mu \mathrm{g} / \mathrm{g})$, vanillin $(17.79 \mu \mathrm{g} / \mathrm{g})$, salicylic acid $(17.32 \mu \mathrm{g} / \mathrm{g})$ and catechin $(5.58 \mu \mathrm{g} / \mathrm{g})$. These findings agreed with Ballesteros et al. [41], who have found out that maltodextrin was the best wall material and freeze-drying the best drying technique for the encapsulation of phenolic compounds. Gallic acid and ferulic acid disappeared during the drying processes, while ellagic acid appeared in spray and microwave-dried samples. Thus, the drying processes affected the individual phenolic compounds differently.

\subsection{Scanning Electron Microscopy}

The micrography of the extract showed amorphous and homogenous features (Figure 6a). These features were reported to be the non-purification of the extract [9]. The introduction of maltodextrin together with the drying processes affected the shape and size of the microcapsules differently. The microcapsules were obtained from the freeze-drying broken plate surface and sawdust-like morphology (Figure 6b). Similar morphology was reported for freeze-drying $[9,41]$. The microcapsules obtained from the spray-drying were irregularly spheric with heterogeneous sizes, where some small particles were inserted in the middle of bigger dimension particles (Figure 6c). This morphology was observed for many products' spray-drying [33,42]. The image of powder issued from microwavedrying (Figure 6d) revealed an amorphous microcapsule with irregularly-shaped smaller particles suspended on its surface. The uniformism of the microstructure of freeze-drying increased the encapsulation powder, protecting more the phenolic compounds. However, the variations in morphological changes for spray-drying and microwave-drying processes might alter the encapsulation power since the variation in the surface area occurring during the encapsulation process provokes more or less degradation of the encapsulated compounds [41]. 

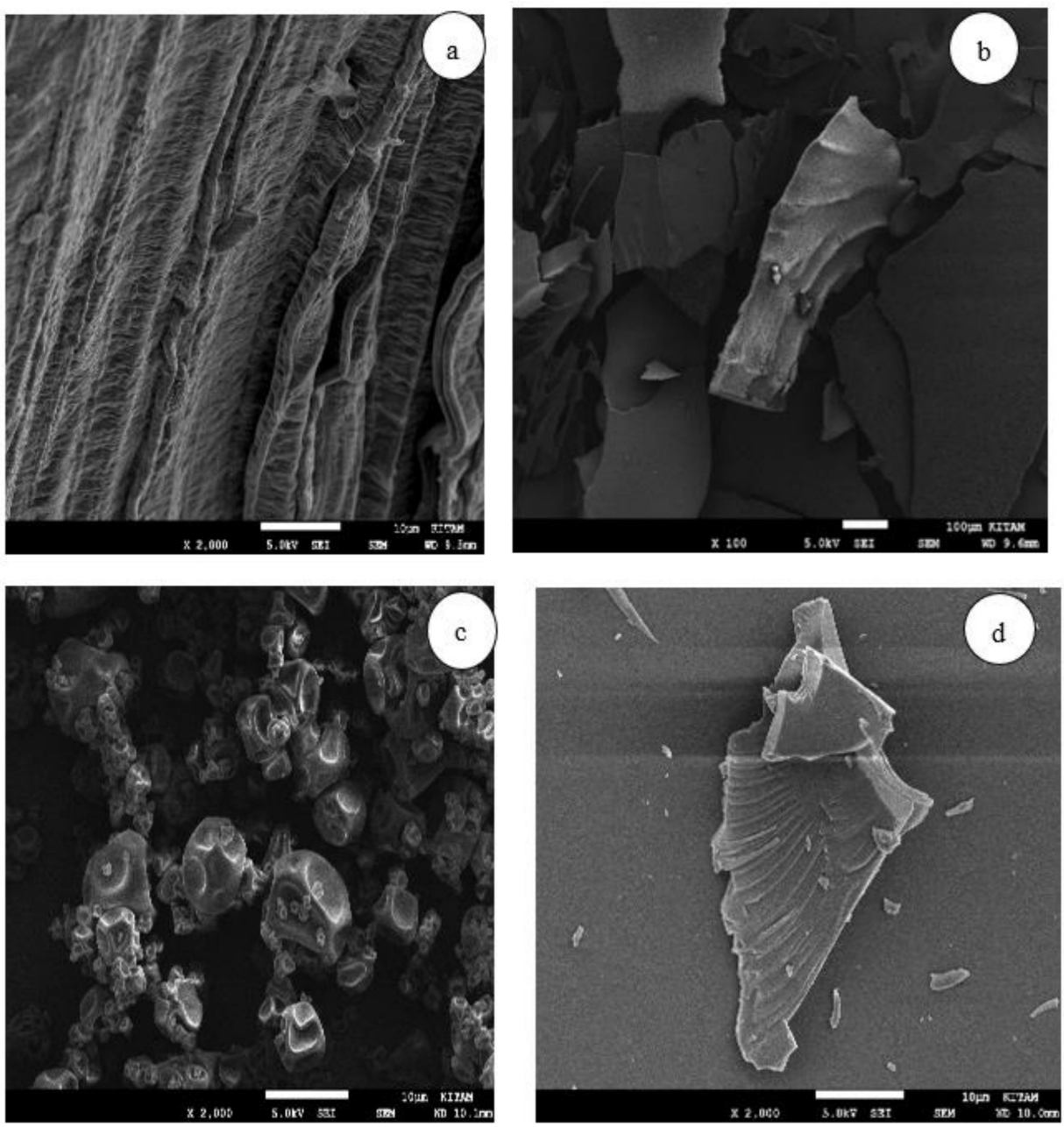

Figure 6. Microstructures of waste extract (a), freeze-dried (b), spray-dried (c), and microwave-dried (d) samples.

\subsection{Differential Scanning Calorimetry (DSC)}

Figure 7 showed the thermograms of maltodextrin and capsules obtained from differential scanning calorimetry and the glass transition temperatures were given in Table 6. Figure 7 a exhibited an endothermic peak at $155.34{ }^{\circ} \mathrm{C}$ with an onset at $153.98^{\circ} \mathrm{C}$ and an endpoint at $159.62{ }^{\circ} \mathrm{C}$, corresponding to the glass transition temperature maltodextrin (Figure 7a). Similarly, Kurozawa et al. [43] and Deschamps et al. [44] have reported a glass transition temperature of $160^{\circ} \mathrm{C}$ for maltodextrin.

Table 6. Glass transition temperatures of maltodextrin and encapsulated samples.

\begin{tabular}{cccc}
\hline \multirow{2}{*}{ Products } & \multicolumn{3}{c}{ Glass Transition Temperatures $\left({ }^{\circ} \mathbf{C}\right)$} \\
\cline { 2 - 4 } & Onset & Peak & End \\
\hline Maltodextrin & 153.98 & 155.34 & 159.62 \\
Freeze-dried sample & 146.34 & 148.25 & 153.72 \\
Spray-dried sample & 141.50 & 143.40 & 148.93 \\
Microwave-dried sample & 169.44 & 171.09 & 175.24 \\
\hline
\end{tabular}



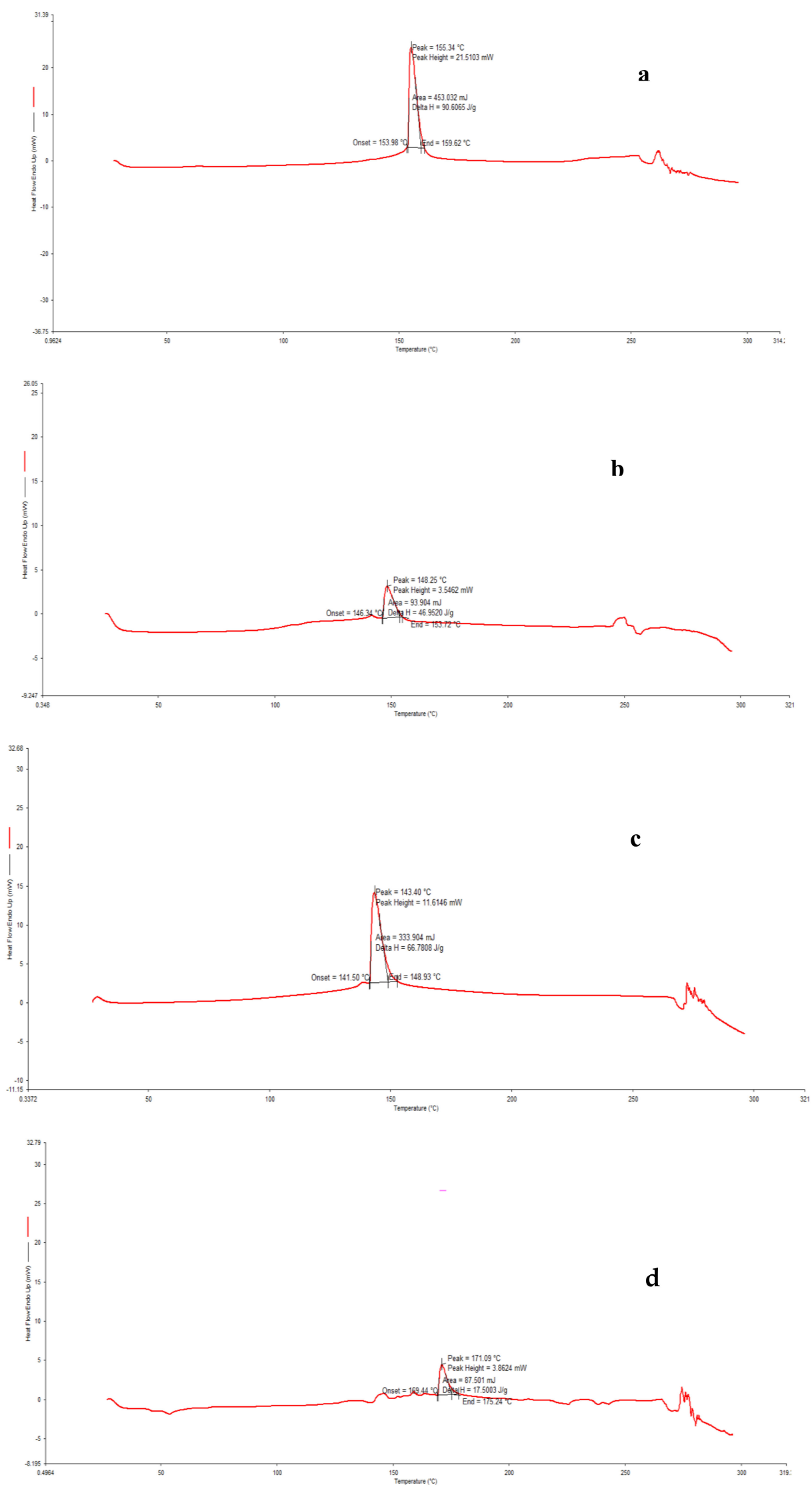

Figure 7. DSC thermograms of maltodextrin (a), freeze-dried (b), spray-dried (c), and microwave-dried (d) samples. 
As can be seen, the encapsulated products' glass transition temperatures were close to the value of the encapsulating agent, guaranteeing the effectiveness of the encapsulation processes. After freeze-drying and spray-drying, the partial disappearance of the thermal events (Figure $7 \mathrm{~b}, \mathrm{c}$ ) was observed with lower glass transition temperatures of $148.25^{\circ} \mathrm{C}$ and $143.40^{\circ} \mathrm{C}$, respectively, when compared to the glass transition temperature of the encapsulating agent. This observation denoted that the guest molecule 46es integrated the encapsulating agent to form inclusive complexes [45,46]. Regarding the microwavedrying (Figure $7 \mathrm{~d}$ ), the glass transition temperature of the encapsulated product $\left(171.09^{\circ} \mathrm{C}\right)$ was higher than the value of the glass transition temperature of an encapsulating agent, suggesting that the desolvation or loss of the guest molecules occurred [47].

\subsection{Fourier Transform Infrared (FTIR) Analysis}

The FTIR spectra of encapsulated phenolic compounds of cornsilk in maltodextrin using freeze-drying, spray-drying, and microwave-drying showed several relevant peaks (Figure 8). The FTIR spectra were in the range of $500-4000 \mathrm{~cm}^{-1}$ tendencies for the wall material and freeze, microwave, and spray-dried products. In all samples, the peaks existent in frequencies between 2800 and $3700 \mathrm{~cm}^{-1}$ were predominantly assigned to hydrogen bonds (O-H stretch), carboxylic acids, and residual water $[48,49]$. The peak at $2900 \mathrm{~cm}^{-1}$ frequency was related to the symmetric and asymmetric stretching of the C-H bond in methyl groups [49] or belonged to the aromatic C-H bond. The same peak at 2930 $\mathrm{cm}^{-1}$ frequency was linked to $\mathrm{C}-\mathrm{H}_{2}, n \mathrm{C}-\mathrm{H}_{3}$ stretching of polyphenolic compounds [41]. The peaks at $1600-1650 \mathrm{~cm}^{-1}$ frequencies associated to $C-C$ or $C=C$ bonds, $1063 \mathrm{~cm}^{-1}$ to $\mathrm{C}-\mathrm{O}$ or $\mathrm{C}-\mathrm{O}-\mathrm{C}$ bonds, at $1450-1300 \mathrm{~cm}^{-1}$ bonds to $-\mathrm{CH} 2,-\mathrm{CH}$, and $=\mathrm{CH}$ bonds were assigned to carbohydrates of maltodextrin [49] and phenolic compounds [49-51]. The FTIR spectra presented similar peaks for the wall material and freeze, microwave, and spraydried products, indicating that the encapsulating agent successfully covered the extracts. Moreover, the peaks of the spectra of freeze, microwave, and spray-dried products were more pronounced, suggesting that the extracts were incorporated in maltodextrin [52].

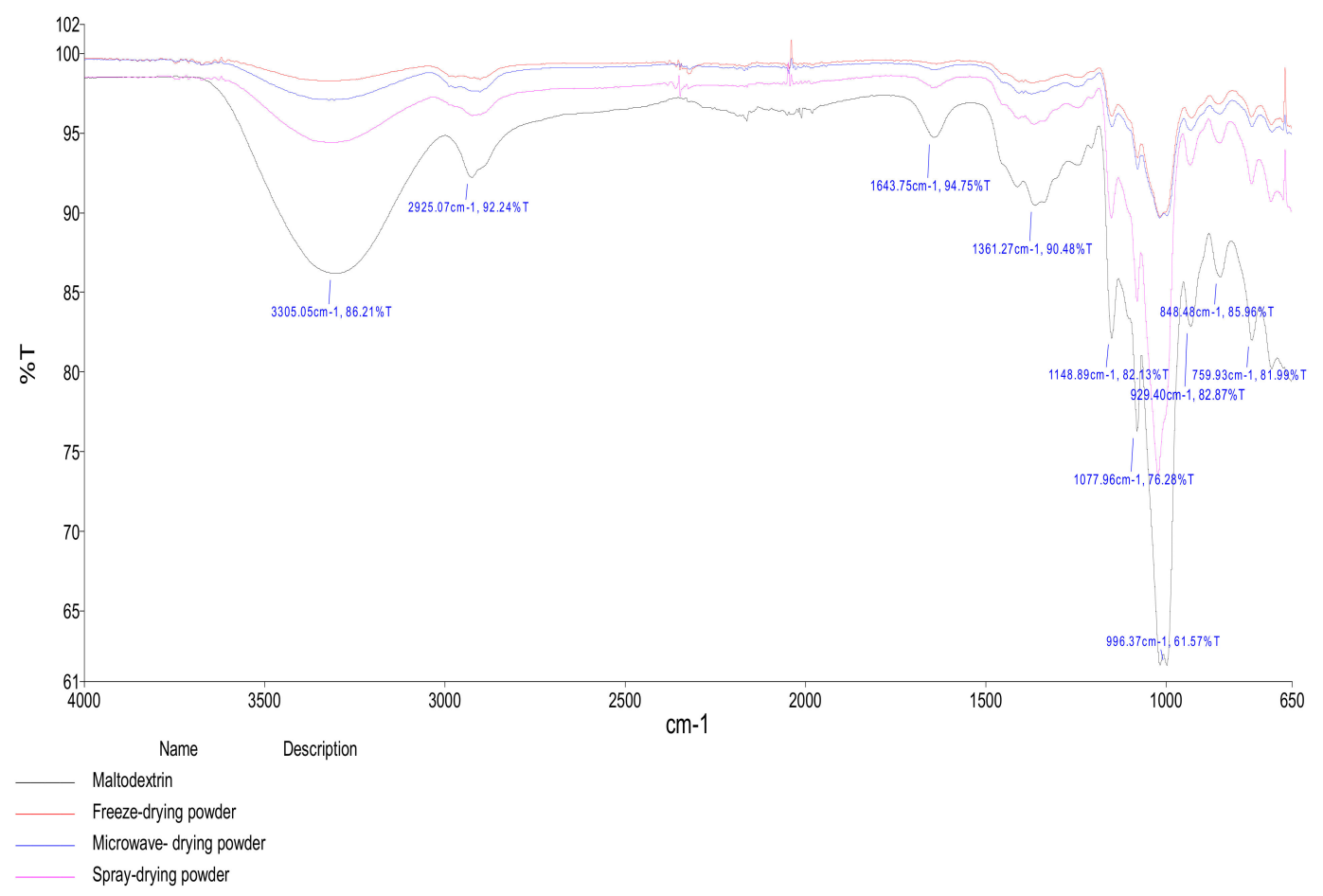

Figure 8. FTIR diagrams of maltodextrin and encapsulated products. 


\subsection{Physical Characteristics of Powders}

The physical properties of encapsulated samples of cornsilk are given in Table 7 . The matter was from $98.10 \%, 98.14 \%$ and $98.23 \%$ in microcapsules dried with freeze-drying, spray-drying and microwave-drying, respectively. The water activity $\left(\mathrm{a}_{\mathrm{w}}\right)$ is the availability of free water in a food system responsible for biochemical activities. The microcapsules produced by spray-drying had significantly higher water activity $(0.1627 \pm 0.0004)$ than those produced by microwave-drying $(0.0873 \pm 0.0245)$ and freeze-drying $(0.0401 \pm 0.0034)$. According to Belscak-Cvitanovic et al. [53], low water content (less than 5\%) guarantees long-term stability and adequate packing as well as prolonged storage. The powders produced by spray-drying, microwave-drying, and freeze-drying could be considered microbiologically and enzymatically stable as they displayed water activities lower than 0.60 [33,54]. Our results are in agreement with those reported by Papoutsis et al. [33], who have observed that the citrus byproduct extracts encapsulated by spray-drying using soybean protein isolate or t-carrageenan as encapsulating agents had higher water activity than those encapsulated by freeze-drying.

Table 7. Physical properties of microencapsulated powders.

\begin{tabular}{|c|c|c|c|c|c|c|}
\hline Treatments & Dry Matter (\%) & Water Activity & $\begin{array}{l}\text { Bulk Density } \\
\qquad\left(\mathrm{g} / \mathrm{cm}^{3}\right)\end{array}$ & $\begin{array}{c}\text { Tapped Bulk } \\
\text { Density }\left(\mathrm{g} / \mathrm{cm}^{3}\right)\end{array}$ & Carr's Index $(\%)$ & Solubility $(\%)$ \\
\hline Microwave-drying & $98.23 \pm 0.00 \mathrm{a}$ & $0.0873 \pm 0.0245 b$ & $0.49 \pm 0.01 \mathrm{a}$ & $0.59 \pm 0.00 \mathrm{a}$ & $17.00 \pm 1.41 c$ & $99.95 \pm 0.070 \mathrm{a}$ \\
\hline Freeze-drying & $98.10 \pm 0.00 \mathrm{a}$ & $0.0401 \pm 0.0034 c$ & $0.11 \pm 0.00 b$ & $0.15 \pm 0.01 c$ & $27.00 \pm 4.24 b$ & $90.45 \pm 0.91 b$ \\
\hline Spray-drying & $98.15 \pm 0.00 \mathrm{a}$ & $0.1627 \pm 0.0004 a$ & $0.20 \pm 0.00 c$ & $0.39 \pm 0.01 b$ & $48.00 \pm 0.00 \mathrm{a}$ & $99.95 \pm 0.070 \mathrm{a}$ \\
\hline
\end{tabular}

Different letters in the same column mean significant difference at $\mathrm{p} \leq 0.05$.

The microcapsules had good solubility of $90.45 \%$ in freeze-drying, $95.95 \%$ in spraydrying and $95.95 \%$ in microwave-drying samples. The highest solubility was found with spray-drying and in microwave-drying samples because produced small size particles which submerged and dissolved rapidly in water. High solubility is desired since it increases the bioavailability of the encapsulated products $[55,56]$. In accordance with several studies [55,57], the present study revealed high solubilities $(>90 \%)$ of the powders produced with maltodextrin. Independently to the drying techniques, the use of maltodextrin as the encapsulating agent facilitated the solubility of the powders, since maltodextrin has shown good solubility attributed to its hydrophilic character [57].

The bulk and tapped bulk densities are essential criteria for storage and packaging. The powders that displayed low bulk densities are more subjected to oxidation and have low storage stability because of more air between their cavities [58]. As can be seen in Table 7 , the powder produced by microwave-drying provided significantly higher bulk density $\left(0.49 \mathrm{~g} / \mathrm{cm}^{3}\right)$ than those of spray-drying powder $\left(0.20 \mathrm{~g} / \mathrm{cm}^{3}\right)$ and freeze-drying $\left(0.11 \mathrm{~g} / \mathrm{cm}^{3}\right)$. Likewise, the powder produced by microwave-drying had significantly higher tapped bulk density $\left(0.59 \mathrm{~g} / \mathrm{cm}^{3}\right)$ than those of spray-drying $\left(0.39 \mathrm{~g} / \mathrm{cm}^{3}\right)$ and freeze-drying $\left(0.15 \mathrm{~g} / \mathrm{cm}^{3}\right)$. Peleg and Bagley [59] have affirmed that the bulk density of food processed to powder varies from 0.4 to 0.95 . Not far from our findings, Che Man et al. [60] have found that the spray-dried products had a higher density than freezedried products. Carr's index is generally used to evaluate the flow properties of powders. Carr's index was 17.00, 27.00 and $48.00 \%$ for microwave, freeze and spray-dried products, respectively. According to the classification of Turchiuli et al. [61], microwave, freeze and spray-dried samples represented good, bad and very bad flowability, respectively. The bad Carr's index of freeze and spray-dried samples might be due to higher moisture content which causes particles to stick and increases the resistance to flow [62]. It might also due small size and irregular shape of these microcapsules [61,62]. 


\section{Conclusions}

The response surface methodology was applied to determine the conditions that provide the highest values of TPC, TFC, FRAP and DPPH of cornsilk. The optimum conditions were $0.5 \mathrm{~g}$ for solid load, $62.10 \mathrm{~min}$ for decoction time and $80^{\circ} \mathrm{C}$ for temperature. At the optimum conditions, the predicted results were $46.39 \mathrm{mg} \mathrm{GAE} / \mathrm{g}, 6.29 \mathrm{mg}$ ECE/g, 109.28 $\mathrm{mmol} \mathrm{TE} / \mathrm{g}$, and $160.72 \mathrm{mmol}$ ISE/g for TPC, TFC, DPPH radical scavenging, and FRAP, respectively, whereas the experimental results were found close to the predicted values as $58.87 \pm 1.38 \mathrm{mg} \mathrm{GAE} / \mathrm{g}, 6.64 \pm 0.12 \mathrm{mg}$ ECE$/ \mathrm{g}, 132.63 \pm 1.66 \mathrm{mmol} \mathrm{TE} / \mathrm{g}$, and $172.30 \pm$ 3.40 for TPC, TFC, DPPH radical scavenging, and FRAP, respectively. The efficiency of 98.85 $\pm 0.90 \%, 97.95 \pm 4.21 \%, 70.39 \pm 6.20 \%, 82.45 \pm 0.89 \%$ was obtained for TPC, TFC, DPPH radical scavenging, and FRAP, respectively. The results of antioxidant properties showed that the freeze-drying provided the highest efficiency. The highest recovery of phenolic compounds, microstructure, thermograms, and FTIR of the encapsulated samples showed that the encapsulation process was successful, and the freeze-drying was the best drying technique. The glass transition temperatures were $148.25^{\circ} \mathrm{C}, 143.40^{\circ} \mathrm{C}$, and $171.09^{\circ} \mathrm{C}$ for freeze-dried, spray-dried, and microwave-dried samples. The microwave-dried samples displayed the highest bulk and tapped bulk densities, which are desirable. However, the spray-dried samples had increased water activity, while the lowest values were found in freeze-dried and microwave-dried samples. This work confirmed the feasibility of the encapsulation of phenolic compounds of a cornsilk extract with maltodextrin using freeze-drying, spray-drying, and microwave-drying. Further studies should be carried out on the bioavailability and anti-microbial properties of the encapsulated products.

Author Contributions: Conceptualization, H.P., O.Z., M.G., and I.K.; methodology, H.P., O.Z., M.G., and I.K.; validation, I.K., C.M.G., and T.M.S.A.; formal Analysis, H.P., O.Z. and M.G.; data curation, I.K., C.M.G., and T.M.S.A.; writing—original draft preparation, O.Z.; writing-review and editing, I.K., C.M.G., and T.M.S.A.; supervision, I.K.; project administration, I.K. and C.M.G.; funding acquisition, I.K., C.M.G., and T.M.S.A. All authors have read and agreed to the published version of the manuscript.

Funding: This research received no external funding.

Institutional Review Board Statement: Not applicable.

Informed Consent Statement: Not applicable.

Data Availability Statement: Data sharing not applicable.

Acknowledgments: The participation of authors Turki M.S. Aldawoud and Charis M. Galanakis in this work was supported by the Researchers Supporting Project number (RSP-2021/197) of King Saud University, Riyadh, Saudi Arabia.

Conflicts of Interest: The authors declare no conflict of interest.

\section{References}

1. Galanakis, C.M.; Aldawoud, T.M.S.; Rizou, M.; Rowan, N.; Ibrahim, S. Food ingredients and active compounds against the coronavirus disease (COVID-19) pandemic: A Comprehensive Review. Foods 2020, 9, 1701. [CrossRef]

2. Pappas, E.; Schaich, K. Phytochemicals of cranberries and cranberry products: Characterization, potential health effects, and processing stability. Crit. Rev. Food Sci. Nutr. 2009, 49, 741-781. [CrossRef]

3. Esfanjani, A.F.; Assadpour, E.; Jafari, S.M. Improving the bioavailability of phenolic compounds by loading them within lipid-based nanocarriers. Trends Food Sci. Technol. 2018, 79, 56-66. [CrossRef]

4. Galanakis, C.M. Functionality of food components and emerging technologies. Foods 2021, 10, 128. [CrossRef]

5. Betz, M.; Steiner, B.; Schantz, M.; Oidtmann, J.; Mäder, K.; Richling, E.; Kulozik, U. Antioxidant capacity of bilberry extract microencapsulated in whey protein hydrogels. Food Res. Int. 2012, 47, 51-57. [CrossRef]

6. Jia, Z.; Dumont, M.-J.; Orsat, V. Encapsulation of phenolic compounds present in plants using protein matrices. Food Biosci. 2016, 15, 87-104. [CrossRef]

7. Halliwell, B. Are polyphenols antioxidants or pro-oxidants? What do we learn from cell culture and in vivo studies? Arch. Biochem. Biophys. 2008, 476, 107-112. [CrossRef] 
8. Saénz, C.; Tapia, S.; Chávez, J.; Robert, P. Microencapsulation by spray drying of bioactive compounds from cactus pear (Opuntia ficus-indica). Food Chem. 2009, 114, 616-622. [CrossRef]

9. da Rosa, C.G.; Borges, C.D.; Zambiazi, R.C.; Rutz, J.K.; da Luz, S.R.; Kumreich, F.D.; Benvenutti, E.V.; Nunes, M.R. Encapsulation of the phenolic compounds of the blackberry (Rubus fructicosus). LWT Food Sci. Technol. 2014, 58, 527-533. [CrossRef]

10. Nedovic, V.; Kalusevic, A.; Manojlovic, V.; Levic, S.; Bugarski, B. An overview of encapsulation technologies for food applications. 11th international congress on engineering and food (ICEF11). Procedia Food Sci. 2011, 1, 806-1815. [CrossRef]

11. Zheng, L.; Ding, Z.; Zhang, M.; Sun, J. Microencapsulation of bayberry polyphenols by ethyl cellulose: Preparation and characterization. J. Food Eng. 2011, 104, 89-95. [CrossRef]

12. Sarfarazi, M.; Jafari, S.M.; Rajabzadeh, G.; Galanakis, C.M. Evaluation of microwave-assisted extraction technology for separation of bioactive components of saffron (Crocus sativus L.). Ind. Crops Prod. 2020, 145, 111978. [CrossRef]

13. Gouin, S. Microencapsulation. Trends Food Sci. Technol. 2004, 15, 330-347. [CrossRef]

14. Cilek, B.; Luca, A.; Hasirci, V.; Sahin, S.; Sumnu, G. Microencapsulation of phenolic compounds extracted from sour cherry pomace: Effect of formulation, ultrasonication time and core to coating ratio. Eur. Food Res. Technol. 2012, 235, 587-596. [CrossRef]

15. Liu, J.; Wang, C.; Wang, Z.; Zhang, C.; Lu, S.; Liu, J. The antioxidant and free-radical scavenging activities of extract and fractions from corn silk (Zea mays L.) and related flavone glycosides. Food Chem. 2011, 126, 261-269. [CrossRef]

16. Velazquez, D.V.O.; Xavier, H.S.; Batistac, J.E.M.; de Castro-Chaves, C. Zea mays L. extracts modify glomerular function and potassium urinary excretion in conscious rats. Phytomedicine 2005, 12, 363-369. [CrossRef]

17. Nurhanan, A.R.; Rosli, W.I.W. Nutritional compositions and antioxidative capacity of the silk obtained from immature and mature corn. J. King Saud Univ. Sci. 2014, 26, 119-127.

18. Fatima, A.; Agrawal, P.; Singh, P.P. Herbal option for diabetes: An overview. Asian Pac. J. Trop. Dis. 2012, 2, S536-S544. [CrossRef]

19. Saheed, S.; Oladipipo, A.E.; Abdulazeez, A.A.; Olarewaju, S.A.; Ismaila, N.O.; Emmanuel, I.A.; Fatimah, Q.D.; Aisha, A.Y. Toxicological evaluations of Stigma maydis (corn silk) aqueous extract on hematological and lipid parameters in Wistar rats. Toxicol. Rep. 2015, 2, 638-644. [CrossRef]

20. Lee, E.Y.; Kim, S.L.; Kang, H.J.; Kim, M.H.; Ha, A.W.; Kim, W.K. High maysin corn silk extract reduces body weight and fat deposition in C57BL/6J mice fed high-fat diets. Nutr. Res. Pract. 2016, 10, 575-582. [CrossRef]

21. Bai, H.; Hai, C.; Xi, M.; Liang, X.; Liu, R. Protective effect of maize silks (Maydis stigma) ethanol extract on radiation-induced oxidative stress in mice. Plant Foods Hum. Nutr. 2010, 65, 271-276. [CrossRef]

22. Al-Oqail, M.M.; Al-Sheddi, E.S.; Farshori, N.N.; Al-Massarani, S.M.; Al-Turki, E.A.; Ahmad, J.; Al-Khedhairy, A.A.; Siddiqui, M.A. Corn silk (Zea mays L.) induced apoptosis in human breast cancer (MCF-7) cells via the ROS-mediated mitochondrial pathway. Oxid. Med. Cell. Longev. 2019, 1-9. [CrossRef]

23. Zeringue, H.J. Identification and effects of maize silk volatiles on cultures of Aspergillus flavus. J. Agric. Food Chem. 2000, 48, 921-925. [CrossRef] [PubMed]

24. El-Ghorab, A.; El-Massry, K.F.; Shibamoto, K. Chemical composition of the volatile extract and antioxidant activities of the volatile and nonvolatile extracts of Egyptian Cornsilk (Zea mays L.). J. Agric. Food Chem. 2007, 55, 9124-9127. [CrossRef] [PubMed]

25. Nurhanan, A.R.; Rosli, W.I.W.; Mohsin, S.S. Total polyphenol content and free radical scavenging activity of cornsilk (Zea mays hairs). Sains Malays. 2012, 41, 1217-1221.

26. Ramessar, K.; Sabalza, M.; Capell, T.; Christou, P. Maize plants: An ideal production platform for effective and safe molecular pharming. Plant Sci. 2008, 174, 409-419. [CrossRef]

27. Zinoviadou, K.G.; Galanakis, C.M.; Brnčić, M.; Grimi, N.; Boussetta, N.; Mota, M.J.; Saraiva, J.A.; Patra, A.; Tiwari, B.; Barba, F.J. Fruit juice sonication: Implications on food safety, physicochemical and nutritional properties. Food Res. Int. 2015, 77, 743-752. [CrossRef]

28. Heng, W.W.; Xiong, L.W.; Ramanan, R.N.; Hong, T.L.; Kong, K.W.; Galanakis, C.M.; Prasad, K.N. Two level factorial design for the optimization of phenolics and flavonoids recovery from palm kernel byproduct. Ind. Crops Prod. 2015, 63, $238-248$.

29. Kovacevic, D.B.; Barba, F.J.; Granato, D.; Galanakis, C.M.; Herceg, Z.; Dragovic-Uzelac, V.; Prutnik, P. Pressurized hot water extraction (PHWE) for the green recovery of bioactive compounds from steviol glycosides from Stevis rebaudiana Bertoni Leaves. Food Chem. 2018, 254, 150-157. [CrossRef]

30. Nagarajan, J.; Prasad, N.K.; Ramakrishnan, N.R.; Raghunandan, M.E.; Galanakis, C.M.; Wei, O.C. A facile water-induced complexation of lycopene and pectin from pink guava byproduct: Extraction, characterization and kinetic studies. Food Chem. 2019, 296, 47-55. [CrossRef]

31. Zannou, O.; Koca, I. Optimization and stabilization of the antioxidant properties from Alkanet (Alkanna tinctoria) with natural deep eutectic solvents. Arab. J. Chem. 2020, 13, 6437-6450. [CrossRef]

32. Zannou, O.; Koca, I.; Aldawoud, T.M.S.; Galanakis, C.M. Recovery and stabilization of anthocyanins and phenolic antioxidants of roselle (Hibiscus sabdariffa L.) with hydrophilic deep eutectic solvents. Molecules 2020, 25, 3715. [CrossRef]

33. Papoutsis, K.; Golding, J.; Vuong, Q.; Pristijono, P.; Stathopoulos, C.; Scarlett, C.; Bowyer, C.M. Encapsulation of citrus by-product extracts by spray-drying and freeze-drying using combinations of maltodextrin with soybean protein and ı-carrageenan. Foods 2018, 7, 115. [CrossRef]

34. Fazaeli, M.; Emam-Djomeh, Z.; Kalbasi Ashtari, A.; Omid, M. Effect of spray drying conditions and feed composition on the physical properties of black mulberry juice powder. Food Bioprod. Process. 2012, 90, 667-675. [CrossRef] 
35. Santhalakshmy, S.; Bosco, S.J.D.; Francis, S.; Sabeena, M. Effect of inlet temperature on physicochemical properties of spray-dried jamun fruit juice powder. Powder Technol. 2015, 274, 37-43. [CrossRef]

36. Zannou, O.; Pashazadeh, H.; Ghellam, M.; Hassan, A.M.A.; Koca, I. Optimization of drying temperature for the assessment of functional and physical characteristics of autumn olive berries. Optimization of drying temperature for the assessment of functional and physical characteristics of autumn olive berries. J. Food Process. Preserv. 2021. [CrossRef]

37. Ebrahimzadeh, M.A.; Pourmorad, F.; Hafezi, S. Antioxidant activities of Iranian corn silk. Turk. J. Biol. 2008, 32, $43-49$.

38. Pashazadeh, H.; Zannou, O.; Koca, I. Modeling and optimization of drying conditions of dog rose for preparation of a functional tea. J. Food Process Eng. 2021, 44, e13632. [CrossRef]

39. Nurraihana, H.; Wan Rosli, W.I.; Sabreena, S.; Norfarizan-Hanoon, N.A. Optimisation extraction procedure and identification of phenolic compounds from fractional extract of corn silk (Zea mays hair) using LC-TOF/MS system. J. Food Meas. Charact. 2018, 12, 1852-1862. [CrossRef]

40. Aires, A.; Carvalho, R. Compositional Study and antioxidant potential of polyphenols extracted from corn by-products, using ultrasound extraction method. Austin Chromatogr. 2016, 3, 1043.

41. Ballesteros, L.F.; Ramirez, M.J.; Orrego, C.E.; Teixeira, J.A.; Mussatto, S.I. Encapsulation of antoxidant phenolic compounds extracted by spent coffee grounds by freeze-drying and spray-drying using different coating materials. Food Chem. 2017, 237, 623-631. [CrossRef]

42. Robert, P.; Gorena, T.; Romero, N.; Sepulveda, E.; Chavez, J.; Saenz, C. Encapsulation of polyphenols and anthocyanins from pomegranate (Punica granatum) by spray drying. Int. J. Food Sci. Technol. 2010, 45, 1386-1394. [CrossRef]

43. Kurozawa, L.; Park, K.; Hubinger, M. Effect of maltodextrin and gum arabic on water sorption and glass transition temperature of spray dried chicken meat hydrolysate protein. J. Food Eng. 2009, 91, 287-296. [CrossRef]

44. Deschamps, N.; Palzer, S.; Roos, Y.H.; Fitzpatrick, J.J. Glass transition and flowability/caking behaviour of maltodextrin DE 21. J. Food Eng. 2013, 119, 809-813. [CrossRef]

45. Mourtzinos, I.; Kalogeropoulos, N.; Papadakis, S.E.; Konstantinou, K.; Karathanos, V.T. Encapsulation of nutraceutical monoterpenes in $\beta$-cyclodextrin and modified starch. J. Food Sci. 2008, 73, S89-S94. [CrossRef]

46. Cevallos, P.A.P.; Buera, M.P.; Elizalde, B.E. Encapsulation of cinnamon and thyme essential oils components (cinnamadehyde and thymol) in $\beta$-cyclodextrin: Effect of interactions with water on complex stability. J. Food Eng. 2010, 99, 70-75. [CrossRef]

47. Delgado, A.Y.C.; Velásquez, H.J.C.; Molina, D.A.R. Thermal and thermodynamic characterization of a dye powder from liquid turmeric extracts by spray drying. Rev. Fac. Nac. Agron. 2016, 69, 7845-7854. [CrossRef]

48. He, J.; Rodriguez-Saona, L.E.; Giusti, M.M. Midinfrared spectroscopy for juice authentication rapid differenciation commerciatial juices. J. Agric. Food Chem. 2007, 55, 4443-4452. [CrossRef]

49. Sarabandi, K.; Jafari, S.M.; Mahoonak, A.S.; Mohammadi, A. Application of gum Arabic and maltodextrin for encapsulation of eggplant peel extract as a natural antioxidant and color source. Int. J. Biol. Macromol. 2019, 140, 59-68. [CrossRef]

50. Lu, X.; Ross, C.F.; Powers, J.R.; Aston, D.E.; Rasco, B.A. Determination of total phenolic content and antioxidant activity of Garlic (Allium sativum) and Elephant Garlic (Allium ampeloprasum) by attenuated total reflectance-fourier transformed infrared spectroscopy. J. Agric. Food Chem. 2011, 59, 5215-5221. [CrossRef]

51. Santiago-Adame, R.; Medina-Torres, L.; Gallegos-Infante, J.; Calderas, F.; González-Laredo, R.; Rocha-Guzmán, N.; OchoaMartínez, L.; Bernad-Bernad, M. Spray drying-microencapsulation of cinnamon infusions (Cinnamomum zeylanicum) with maltodextrin. LWT Food Sci. Technol. 2015, 64, 571-577. [CrossRef]

52. Ćujić-Nikolić, N.; Stanisavljević, N.; Šavikin, K.; Kalušević, A.; Nedović, V.; Samardžić, J.; Janković, T. Chokeberry polyphenols preservation using spray drying: Effect of encapsulation using maltodextrin and skimmed milk on their recovery following invitro digestion. J. Microencapsul. 2019, 38, 693-703. [CrossRef]

53. Belscak-Cvitanovic, A.; Lević, S.; Kalušević, A.; Špoljarić, I.; Đorđević, V.; Komes, D.; Mršić, G.; Nedović, V. Efficiency assessment of natural biopolymers as encapsulants of green tea (Camellia sinensis L.) bioactive compounds by spray drying. Food Bioprocess Technol. 2015, 8, 2444-2460. [CrossRef]

54. Yamashita, C.; Chung, M.M.S.; dos Santos, C.; Mayer, C.R.M.; Moraes, I.C.F.; Branco, I. Microencapsulation of an anthocyanin-rich blackberry (Rubus spp.) byproduct extract by freeze-drying. LWT Food Sci. Technol. 2017, 84, 256-262. [CrossRef]

55. Zorzenon, M.R.T.; Formigoni, M.; da Silva, S.B.; Hodas, F.; Piovan, S.; Ciotta, S.R.; Jansen, C.A.; Dacome, A.S.; Pilau, E.J.; Mareze-Costa, C.E.; et al. Spray drying encapsulation of stevia extract with maltodextrin and evaluation of the physicochemical and functional properties of produced powders. J. Food Sci. 2020, 85, 3590-3600. [CrossRef] [PubMed]

56. Siacor, F.D.C.; Lim, K.J.A.; Cabajar, A.A.; Lobarbio, C.F.Y.; Lacks, D.J.; Taboada, E.B. Physicochemical properties of spray-dried mango phenolic compounds extracts. J. Agric. Food Res. 2020, 2, 100048. [CrossRef]

57. Etzbach, L.; Meinert, M.; Faber, T.; Klein, C.; Schieber, A.; Weber, F. Effects of carrier agents on powder properties, stability of carotenoids, and encapsulation efficiency of goldenberry (Physalis peruviana L.) powder produced by co-current spray drying. Curr. Res. Food Sci. 2020, 3, 73-81. [CrossRef]

58. Koç, M.; Koç, B.; Yilmazer, M.S.; Ertekin, F.K.; Susyal, G.; Bagdatlıglu, N. Physicochemical characterization of whole egg powder microencapsulated by spray drying. Dry. Technol. 2011, 29, 780-788. [CrossRef]

59. Peleg, M.; Bagley, E.B. Physical Properties of Foods; Avi Publishing Company: Westport, CT, USA, 1983.

60. Che Man, Y.B.; Irwandi, J.; Abdulla, W.J.W. Effect of different types of maltodextrin and drying methods on physico-chemical and sensory properties of encapsulated durian flavour. J. Sci. Food Agric. 1999, 79, 1075-1080. [CrossRef] 
61. Turchiulia, C.; Fuchs, M.; Bohin, M.; Cuvelier, M.E.; Ordonnaud, C.; Peyrat-Maillard, M.N.; Dumoulin, E. Oil encapsulation by spray drying and fluidised bed agglomeration. Innov. Food Sci. Emerg. Technol. 2005, 6, 29-35. [CrossRef]

62. Arepally, D.; Goswami, T.K. Effect of inlet air temperature and gum Arabic concentration on encapsulation of probiotics by spray drying. LWT Food Sci. Technol. 2019, 99, 583-593. [CrossRef] 